w $34 \mathrm{~ms}$

Vo. $C .73 .4$

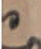

$-2$

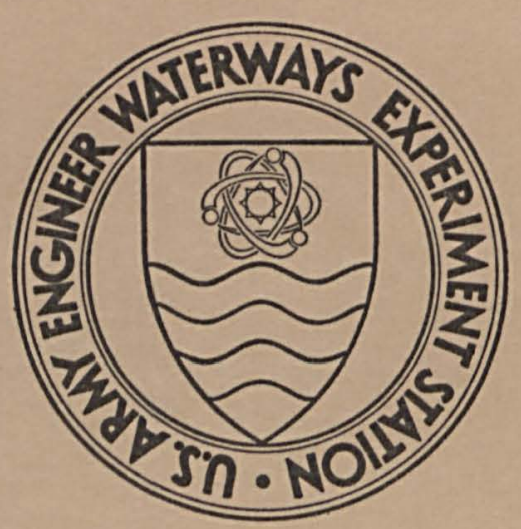

MISCELLANEOUS PAPER C-73-4

IDENTIFICATION OF SAMPLES OF OBJECTS RECOVERED FROM OCEAN FLOOR

by

K. Mather

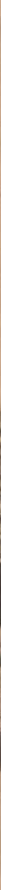

January 1973

Conducted by U. S. Army Engineer Waterways Experiment Station

Concrete Laboratory

Vicksburg, Mississippi 


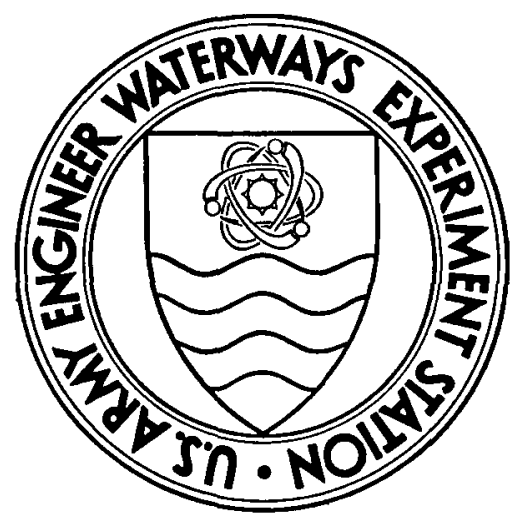

MISCELLANEOUS PAPER C-73-4

\section{IDENTIFICATION OF SAMPLES OF OBJECTS RECOVERED FROM OCEAN FLOOR}

by

K. Mather

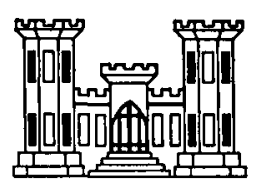

January 1973

Conducted by U. S. Army Engineer Waterways Experiment Station

Concrete Laboratory

Vicksburg, Mississippi 
W34 mi

No.c-73-4

Cop. 2

THE CONTENTS OF THIS REPORT ARE NOT TO BE USED FOR ADVERTISING, PUBLICATION, OR PROMOTIONAL PURPOSES. CITATION OF TRADE NAMES DOES NOT CONSTITUTE AN OFFICIAL ENDORSEMENT OR APPROVAL OF. THE USE OF SUCH COMMERCIAL PRODUCTS. 


\section{Foreword}

An inquiry dated 22 June 1970 was received from Mr. Wyman Harrison of the Virginia Institute of Marine Science requesting that the U. S. Army Engineer Waterways Experiment Station (WES) identify samples of objects recovered from the ocean floor near Bimini.

A reply was prepared by Katharine Mather, Chief, Petrography and $X$-Ray Section, Engineering Sciences Branch, of the WES Concrete Laboratory, Mr. Bryant Mather, Chief, and Director, Concrete Technology Information Analysis Center (CTIAC).

The reply is reproduced herein as CTIAC Report 6. The cost of the reproduction was defrayed by TISA Project 02/07.

During the activities mentioned above, COL Ernest D. Peixotto, $\mathrm{CE}$, was Director of WES and Mr. F. R. Brown was Technical Director. 


\section{Contents}

Page

Foreword

Summary ix

Introduction 1

Action Taken by

Outcome.

Inclosures $1-3$

Appendix A: "Atlantis Undiscovered--Bimini, Bahamas," by $W$. Harrison 


\section{Summary}

Several pieces of objects recovered from the ocean floor near Bimini were examined by $\mathrm{X}$-ray and analyzed petrographically. The objects consisted of calcite, brucite, a complex calcium aluminum hydrate, quartz, hydrogarnet, a little ettringite, and some sort of calcium alumino-ferrite. The objects are believed to be remnants of construction materials that were being transported by ship and subsequently came to rest (perhaps because of shipwreck) on the ocean floor.

A copy of an article written for Nature by Mr. Wyman Harrison in which the findings of the examination mentioned above are cited is included as Appendix A. 
IDENTIFICATION OF SAMPLES OF

OBJECTS RECOVERED FROM OCEAN FLOOR

Introduction

1.. An inquiry was received from Mr. Wyman Harrison of the Virginia Institute of Marine Sciences regarding samples of objects recovered from the ocean near Bimini.

\section{Action Taken by CTIAC}

2. A reply was prepared by Katharine Mather. Some of her comments were:

a. "If the Virginia Institute of Marine Science is an agency of the Commonwealth, Mr. Harrison could consult Howard H. Newlon, Jr., Virginia Highway Research Council, Box 3817, University Station, Charlottesville, Virginia 22903, on possible cooperation in studying Mr. Harrison's problematical objects.

b. "The 27 'cement' objects sampled by Harrison were barrel shaped, $50 \mathrm{~cm}$ in diameter by $70 \mathrm{~cm}$ long found on the sea floor in the Bahamas in 3 to 20 ft of water 'over a fairly wide area,' associated with larger fragments of encrusted fluted marble columns. Putting the dimensions in the English system the objects were 19.7 in. in diameter and 28 in. high; calculated as the volume of a cylinder and not allowing for the bulge this is $4.9 \mathrm{cu} \mathrm{ft}$. If one $94-1 \mathrm{~b}$ contemporary bag of portland cement is about $1 \mathrm{cu}$ ft loose volume, one contemporary barrel ( 4 bags) would be about 4 cu ft.

c. "Kress reported that the PCA by xrd and petrography found brucite, calcite, ettringite, quartz, 'and possibly some hydrated cement.'

d. "We received several pieces, the largest about 5 by $3-1 / 2$ by 1-3/4 in., with an irregular encrusted outer surface, the crust being 1 to about $3 \mathrm{~mm}$ thick, irregular, cream color with a darker mottling, including the attachments of some small plants, at least one foram, and shiny fragments of shell (or microorganisms). The other fresh fracture surfaces on the pieces are as described by Mielenz except that some of the pieces had broken along the random cracks filled by white deposits which he mentions.

e. "The apparent outer crust on the larger piece we received is too irregular to have fitted smoothly against the inside of a barrel or keg of a type with which I am familiar. Maybe it is an 'old' open fracture exposed to the seawater. 
f. "We made a diffraction pattern to explore the suspicion that arose in your mind when you saw the sample and that arose in my mind when I read the PCA's findings on the composition--the suspicion being that the problematical object consisted of hydrated natural cement. We found much the same things as the PCA: calcite $\left(\mathrm{CaCO}_{3}\right)$, brucite $\left(\mathrm{Mg}(\mathrm{OH})_{2}\right)$, a complex calcium aluminate hydrate (either dehydrated calcium aluminate monosulfate, or hemicarbonate), quartz ( $\left.\mathrm{SiO}_{2}\right)$, : hydrogarnet, a little ettringite, possibly some sort of calcium aluminoferrite, conceivably a bit of melilite, quite strong calcium silicate hydrate humps.

g. "Natural cements that we have examined have consisted of poorly crystalline B-dicalcium silicate, better crystalline calcite, crystalline MgO in extremely small crystallites, and--I suspect--sometimes a calcium aluminoferrite and possibly as Mielenz suggests an aluminous melilite. MgO has amounted to 6 to 21 percent, usually showing a characteristics level for a given source--for Rosendale it runs around 20 percent. Brownmiller reported a monocalcium silicate in some samples and we may have had it and not known it. We never verified CaO in ground cements, but Brownmiller had it in clinkers. Natural cements burned in shaft kilns contained everything from raw materials to tricalcium silicate.

h. "The hydration products of Rosendale Natural up to 90 days included a complex calcium aluminate hydrate and calcium hydroxide. However, if a natural cement hydrated in the sea, the complex calcium aluminate hydrate would acquire sulfate from seawater and transform to low sulfate calcium aluminate sulfate and to ettringite. Given time enough, the $\mathrm{MgO}$ would hydrate to $\mathrm{Mg}(\mathrm{OH})_{2}$ and the $\mathrm{Ca}(\mathrm{OH})_{2}$ could go to $\mathrm{CaCO}_{3}$. Volume changes were apparently involved since we find the cracks containing ettringite and calcite.

i. "Mr. Harrison's questions to Paul Klieger:

(1) The material is hydrated natural cement.

(2) See Incl $3 \mathrm{p}$ 14--the material could have been made in England, United States, France, or Belgium.

(3) See Incl 1 p 18 and Incl 2 p 12--natural cement was used for waterproof masonry in all sorts of applications.

(4) Parker's patent was obtained in 1796 (Incl 3) and his cement was used in the Chirk aqueduct (Incl $1 \mathrm{p} \mathrm{18).} \mathrm{The} \mathrm{earliest} \mathrm{pro-}$ duction date was probably 1796; Incl $3 \mathrm{p} 6$ suggests that use of natural cement in general work was less likely after 1850, but I believe it is still produced.

(5) It is not a pozzolan.

(6) It could have hardened in seawater but it cannot be guaranteed that it did.

(7) If $50 \mathrm{~cm}$ in diameter and $70 \mathrm{~cm}$ long (20 in. in diameter and 28 in. long) could be established as the inside dimensions of a cask of cement (see Incl $1 \mathrm{p} 18$ under Thames Tunnel), there would be a clear significance to the dimensions. 
j. "If I were Mr. Harrison, I'd pursue the architectural history of the Bahamas or of the places to. which vessels--which might have wrecked where he found the objects-would have been going. I'd also want a chemical analysis of the hydrated natural cement."

3. The inclosures mentioned above are also included herein.

\section{Outcome}

4. Mr. Harrison subsequently wrote a research report which was published in Nature. A copy of this report is reproduced herein as Appendix A. Katharine Mather's reply to his inquiry was quoted in the Nature article. 
Extractions from "The Early History of Cement in England," Proceedings, 3d International symposium on the Chemistry of Cement, London, 1952, published 1954:

\section{Parker's cement}

Parker's cement, afterwards known as "Roman cement" and used to this day, was described in Parker's specification of 1796 as follows :

"The principle and nature of the said Invention consists in reducing to powder certain stones or argillaceous productions, called noddles of clay, and using thot powder with water, so as to form a mortar or cement stronger and harder than 2ny mortar or cement now prepared by artificial means. I do not know of any precise generieal term for these noddles of clay; but I mean by them, certain stones of clay, or concretions of clay, containing veins of calcareous matter, having frequently, but not always, water in the centre, the cavity of which is covered with small erystals of the above calcareous matter, and the noddles agrecing very nearly in colour with the colour of the bed of clay in or near which they are found. These noddles, on being burnt with a heat stronger than that used for burning lime, generally assume a brown appcaranee, and are a little softened, and when so burnt and softened become warm (but do not slack) by having water thrown upon them, and being reduced to powder after burning, and being mixed with water just suffieient to make into a paste, become indurated in water in the space of an hour, or thereabouts. Any argillaccous stone, then, corresponding with this description, whether known by the name of noddles of elay, or any other name, is the sort and kind only that I mean to appropriate to my own use in the fermentation of my eement."

According to Redgrave" Parker made his cement as follows:

"In preparing and composing this cemerit, Parker broke the noddles of clay into small fragments. These were then burnt in a kiln or furnace with a heat nearly sufficient to vitrify them, then reduced to a pow der by ariy mechanical or other operation, and the powder so obtained was the basis of the cement.

"To compose the cement in the most advantageous manner Parker took two - measures of water and five measures of the powder. He then added the powder to the water, or vice versa, stirring and beating them during the whole time of intermixture. The cement was thus made, and would set or harden in 10-20 minutes after the nixing, either in or out of water." 
Chirk Agueduct

One of the earliest constructions in which Parker's cement was used was the Chirk Aqueduct which carries the Ellesrnere Canal across the Ceriog River from Shropshire to Denbigh."1 The aqueduct is $710 \mathrm{ft}$ long, $22 \mathrm{ft}$ wide and has ten arches of $40 \mathrm{ft}$ span. ${ }^{20}$ It was commenced in 1796 and completed in $1801 . .^{23}$

Instead of using the normal construction of puddled earth, Telford, who was the engineer, decided to construct it with an iron bed which would form a continual tie preventing the side walls from collapsing through lateral pressure of the water. According to Telford's own description, it was "constructed with longitudinal walls instead of being filled with earth, and across thesse the canal bottom was formed by cast-iron plates at each side infixed in square stone masonry." The sides of the canal were made waterproof by ashlar masonry backed with hard burnt bricks laid in Parker's cement. ${ }^{21}$

Thames Tunnel

"Then it (Portand cement) garticularly arrested the notice of Sir Isanibard Brunel, the cninent enginect, and constructor of the Thames Tunnel, who tested it with 'Roman Cernent', until he was thoroughly convinecd of the grent supuriority of the porTLAND, by finding it three times stronger than any other cement then known to the public. Although, at that time, it cost from 20s. to 22s. per cask, besides the carriage to London, yet Sir Isambard Brunei determined (notwithstanding his ability to procure 'Roman' at 12s. p:r cask, delivered on the spot) to adopt PORTIANi chichy-for his puiposes, as its merits sequircd no other recomenendation than ạn irngartial srial. 
Extractions from "The Chemistry of Portland Cement," $2 d$ ed., Reinhold, New York, 1955.

L. J. Vicat. The fragmentary chemical knowledge that had been obtained up to 1818 was coordinated by the eminent French engineer, Vicat ${ }^{17}$, who emphasized what had been implied but not practiced by Smeaton, that, in the absence of the clay or shale occurring naturally in the rock, the same effect may be brought about by the artificial admixture of argillaceous rock with the limestone. Such a procedure had the further advantage that the proportions may be brought to any desired ratio, and hence the properties of the product can be kept under a more uniform and definite control. When the lime content was relatively high, the product after calcination slaked like ordinary quicklime; but if sufficiont argillaceous material was present, it was hydraulic and so was called hydraulic lime. When a considerable amount of magnesia, alumina or ferric oxide was present, the product did not slake but possessed a higher hydraulic value. This was called natural cement. Concerning this material he wrote:

In the present state of our knowledge regarding the different varieties of lime, it is impossible to say whether there exist certain determinate propor. tions of silica and magnesia, etc., which by their intimate association with the same quantity of calcarcous matter are capable of groducing limos of equal energy. But one thing is certain, and this is important to remember, that no perfectly hydraulic mortar exists without silica, and all lime which can be so denominated is found by chenical analysis to contain a certain quantity of clay, made up of silica and alumina in proportions similar to those which constitute the ordinary clays.

In recognition of the value of clays in the raw mixture, Vicat procecded to prepare hydraulic limes in two ways. The best of these, hestates, mas to mix clay in certain proportions with rich lime and calcine the mixture. This he called artificial lime twice kilned. A chcaper method, and one giving a somewhat poorer product, was to mix the clay with a crushed limestone or chalk. But as the mixing and pulverizing were less perfect than in the former casc, the product was less uniform. And he adds with surpising modernism:

We see that, by being able to regulate the proportions, we can give to the facetious lime whatever degrec of energy we pleasc, and cause it at plcasure to equal or surpass the natural limes.

10

James Frost. An early manufacturer to apply these principles was James Frost3, who in 1811 uscd two parts by weight of chalk to one of clay. The product he called Frost's Cement. But by 1822 he had discarded this procedure and in a new patent spccified the use of "limestones or marls, or magnesian limestones or marls, as are entirely or nearly free from any mixture of alumina or argillaccous earth, and contain from 9 to 40 pcr cent of siliceous carth or silica, or combinations of silica and oxides of iron, the silica being in excess and in a fincly divided state." The product obtained from the calcination of this matcrial he called British Cement. 
The Development of the Cement Industry

Robert I.esley ${ }^{9}$ credits. the origin and derelopment of the cement industry in the United States to the sudden large demand for a good hydraulic cement created by the building of our cainals. The first of these was the great Eric Canal, commenced in 1817. The locks, bridges, and aqueducts involved construction which required water-resisting mortar. The first discovery of cement rock in this country was made by Canvas White near Fayetteville in New York State. White took out a patent for the manufacture of natural cement from that rock in 1818, which was later sold by him to the State of $\mathrm{N}^{\mathrm{C}} \mathrm{cW}$ York: for $\$ 10,000$, and this sale resulted in the removal of all manufacturing restrictions. The discovery of cement rock in other districts followed soon, and the natural cement industry became firmly cstablished. 
Extractions from "The Chemistry of Cement and Concrete," St. Martin's Press, New York, 1956:

6

The discovery that a hydraulic cement could be made by calcining nodules of argillaceous limestone, known as septaria, found in certain Tertiary strata, was made in 1796.4 About 1800 the product thus obtained was given the inappropriate and misleading name of Roman coment, from its hydraulic properties, although it in no way resembles the Roman mortar. Being a quick-setting cement, it was found useful in work in contact with water and steadily grew in favour. ${ }^{5}$ Its heyday for civil enginecring work lasted until about 1850 after which it was gradually driven out by Portland cement. About the same time as Roman cement was introduced a similar natural cement was prepared in France from similar concretions found near Boulogne, and deposits of "cement rock," capable of yiclding a hydraulic cement on calcination, were found at Rosendale, and at Louisville, in the United States. It was not long before the American natural cement industry attained great importance.

- Patent by James Parker, of Northfect. No. 2170 (1706).

See A. P. Thurston, Engineering, 147, 757 (1939), for history of Romnn cement.

14

The temperature reached in the calcining of limes is normally below that at which any sintering of the materials occurs, but in the burning of hydraulic limes, if the temperature is too high, a portion of the product may sinter. Such sintered lumps are sometimes separated and form, after grinding, the French "grappier" cement, a product closely akin to the natural cements. The French "Ciment Prompts" and "Ciments Romain" are quick-setting materials produced from certain limestones, but again, in properties, they should probably be classed as natural cements.

Natural Cements. Natural cements are materials formed by calcining a naturally occurring mixture of calcareous and argillaceous substances at a temperature below that at which sintering takes place. The British "Roman" cement which preceded Portland cement, but which is still manufactured on a small scale, and the former American Rock cements, belong to this class. The Belgian " natural Portland cements" were also similar, but burnt at a somewhat higher temperature. These materials represent a group intermediate between the hydraulic limes and Portland cement. Since the composition is governed by that of the naturally occurring raw material, it is more variable than that of artificial mixtures. The importance of this class of cements has now much diminished and in many countries their manufacture has ceased or continues only on a very small scale. 


\section{APPENDIX A}

ATIANTIS UNDISCOVERED--BIMINI, BAHAMAS

Research report by Mr. W. Harrison in "Nature," Vol 230, No. 5292, Macmillan Journals Itd, Washington, 1971 


\section{Alantis Undiscovered - Bimini, Bahamas}

\section{H. HARRISON}

I nuronmental Research Associates Inc., 1456 Ashley Drive, Virginia Beach, Virginia 23454

Underwater remains of an originally cohcrent formation of coquina limestone have been misinterpreted as an "enigmatic" stonework cmplaced by prehistoric meir. Marble and cement cylinders are found nearby. People who require the cylinders to be "pillar fragments" of an Olmec or Atlantean culture might consider a more mundane explanation.

IN 1969, J. M. Valentine described" what he called an "archacological enigma" consisting of "pavenent-like stones at 15 feet off North Bimini". Since then, newspaper reports, at least one magazine article ${ }^{2}$ and two books ${ }^{3}$ have suggested, first, that there is a seawall or roadbed submerged at about $7 \mathrm{~m}$ off the north-west coast of North Bimini (Fig. 1) and, second, that sections of pillars which seem "to have been carved from natural stone" lie at shallow depths off Entrance Point. Last October an advertisement for one of the books, Allantis, by R. Ferro and M. Grumley, appeared in the New York Times, confidently reporting that although ultimately it may turn out that Atlantis is no more than a legendary pot of gold ... Ferro and Grumley discovered unmistakable traces of an ancient civilization-exactly where and when Edgar Cayce prophesied the re-emergence of Attantis. These occurrences have now been carcfully investigated, using SCUBA gear, underwater cameras and hand tools. Most of the underwater work was done by Dr R. J. Byrne and $\mathrm{Mr} \mathrm{M}$. P. Lynch, who also holped in the interpretation of the data. We were guided to the sites by Mr Pino G. Turolla, said to have been the original discoverer ${ }^{1,3}$.

The most obvious "pavement-like stones" or blocks form single or double lines roughly parallel to the present shoreline (Fig. 2A). The blocks here are between 60 and $90 \mathrm{~cm}$ thick, somewhat pillow-shaped in cross scction, their originally right-angled corners having been trimmed back, chiefly by boring molluscs and sea urchins. All of the blocks are of coarse-grained limestone lying on a stratum of denser limestone of finer grain. Shifting sands cover this underlying formation in most places, giving the impression that the blocks have been placed there. Erosion at the interface of the two rock types has caused many of the largest blocks to fracture, either under thcir own weight or when storm swells have caused heaving and fracturing.

Although casual inspection of structures such as the fractured block of Fig. $2 B$ might suggest small slabs that have been cut and fitted, closer examination of the opposing faces of the lifted and the unmoved pieces indicates an exact correspondence of bedding planes and surface morphology, so that all picces are from the same original block. Similarly, the margins of adjacent large blocks correspond to one another, indicating that all blocks have develoned by fracturing of an originally coherent formation. At no place are blocks found to rest on a similar set beneath. Samples of several blocks indicate that all are composed of shell-hash cemented by a blocky calcite, a type that originates only in the fresh water vadose or phreatic zones. The rock was thus a!most certainly lithified during the lower relative sea level of the Pleistocene.
The geological setting of the blocks is important. The three small islands off Paradise Point are composed of 1 cemented wind-blown sand (colianite) above a cemented shell-hash, with an interface roughly $1 \mathrm{~m}$ below low' water. The beds of cemented shell-hash gravels and marine sands extend to at least $2 \mathrm{~m}$ below $\mathrm{MLW}$, so that the sequence of blocks of coquina limestone overlying marine sand limestones to the north-east of the islands is not surprising.

The blocks are believed to have originated as follows. A shell-hash gravel was deposited in shallow water as relative sea level fell during the most recent emergence of the Bahama Banks, and later brought into the fresh water environment. The materials were cemented and joints formed in the material, as is usually the case with limestones ${ }^{4}$. After tivo sets of practically right angle joints had developed, submergence of the area brought the jointed coquina limestone first into the breaking zone of waves and then the offshore zones. Wave action probably caused much of the initial separation into blocks, but when the formation was farther offshore the destructive activity of marine life would have become dominant.

The overall result is a field of blocks that at first sight appear to have been fitted together, and this has led to state-

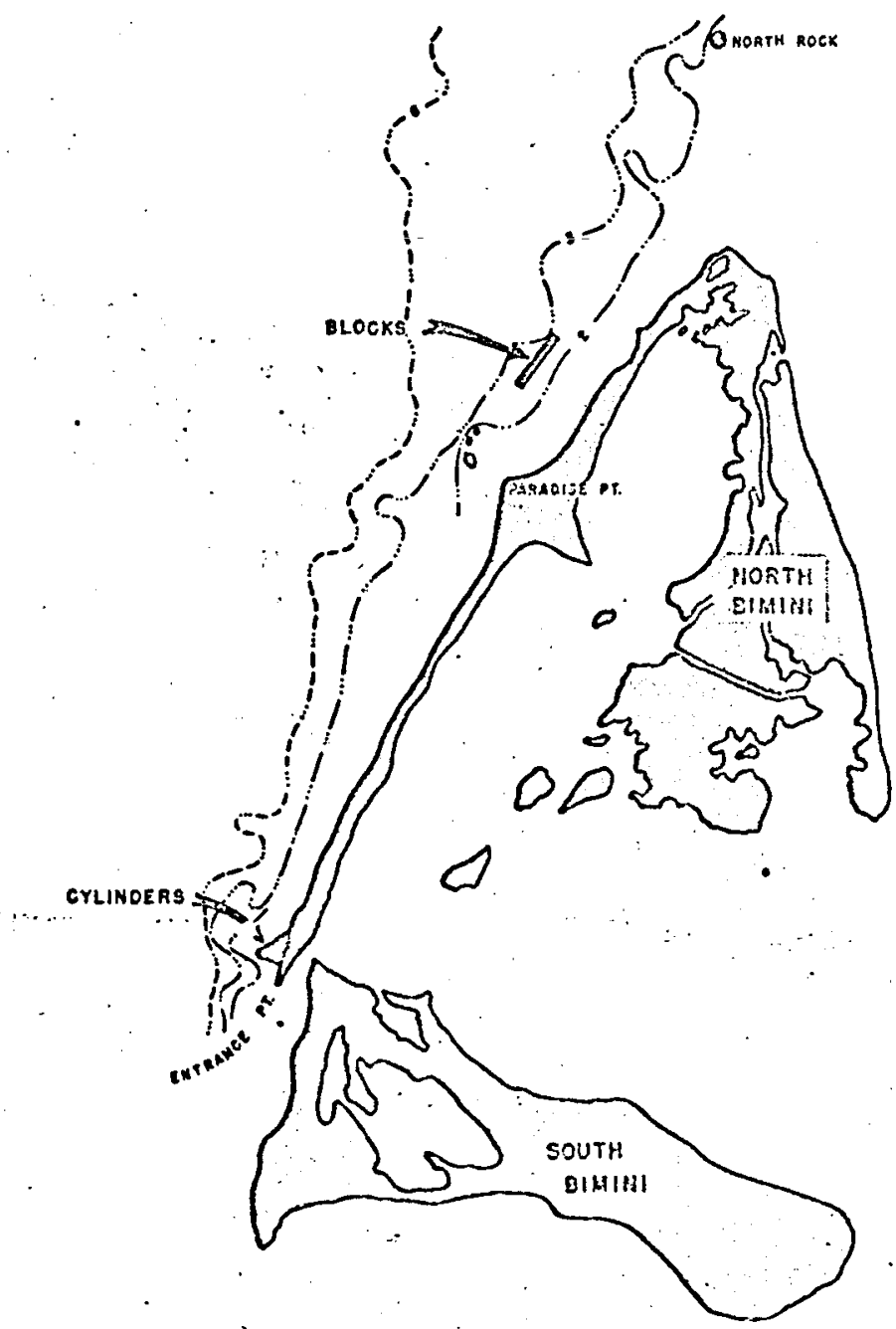

Fig. 1 Map of the Bimini Islands, showing locations of materials referred to in text. Bathymetric contours are in fathoms. 


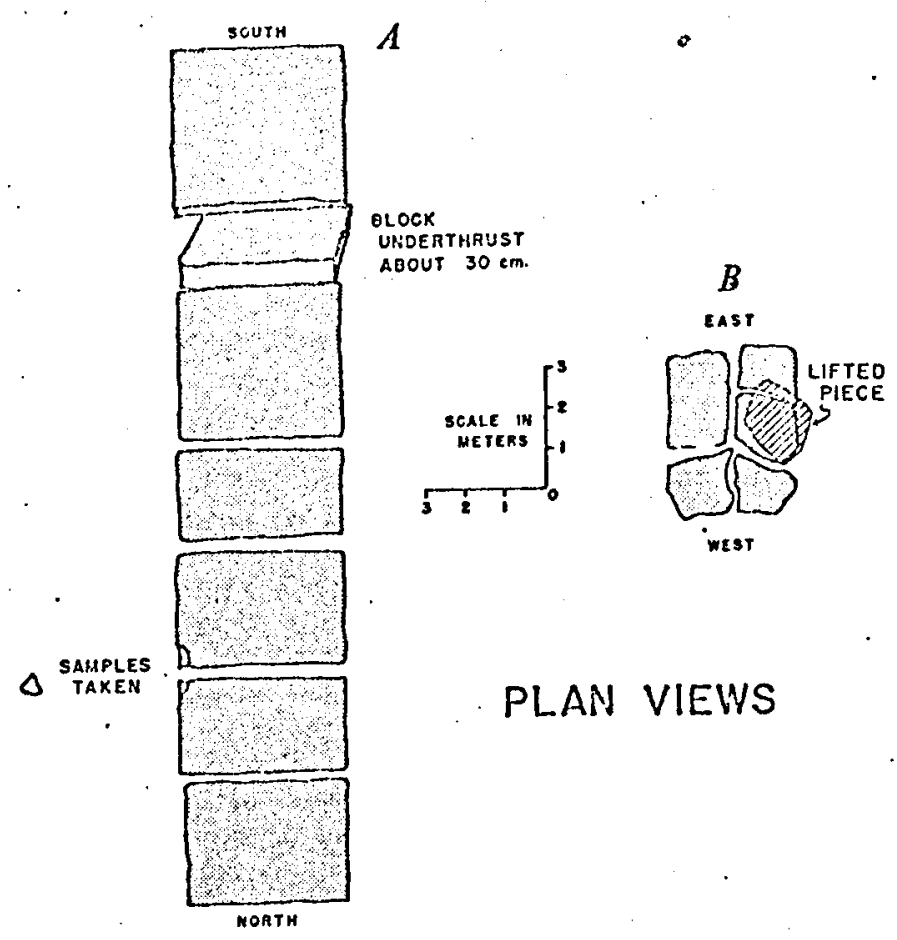

Fig. 2 Dimensions and arrangements of blocks $(A)$ and fragments of a single fractured block $(B)$.

ments" such as, (some) "human agency must have been involved". The blocky remains of the limestone outcrop are, however, no more enigmatic than other subacrial or subaqueous outcrops of jointed limestone found in various stages of fracture and decay in the north-western Bahamas.

The cylinders (Fig. 1), previously called "pillars", raise different considerations. They were found (Fig. 3) in grooves in the limestone country rock running roughly perpendicular to the present shoreline. Such grooves are common at Biminis and other Bahamian islands. Two of the cylinders are composed of marble and have flute-like marks parallel to the long axis. The wavelength of the crests is about $15 \mathrm{~cm}$ and their height about $1.5 \mathrm{~cm}$. The remaining cylinders consist of what is most probably an early natural cement. All of the cylinders are encrusted with a layer of whitish $\mathrm{CaCO}_{3}$, a few $\mathrm{mm}$ thick. Although several of them have been attacked by boring molluses and sea urchins, destruction has been hindered by periods of burial by sand.
Table 1 Eight Measurements of the Circunference of a $68.5 \mathrm{~cm}$. i 2.8 Cylinder, by $10 \mathrm{~cm}$ Intervals

\begin{tabular}{cc} 
Incremental & circumference \\
distance (cm) & 135 (end) \\
0.0 & 152 \\
10.0 & 160 \\
10.0 & 165 \\
10.0 & 163 \\
10.0 & 157 \\
10.0 & 147 \\
10.0 & 142 (cnd) \\
\hline 8.5 & \\
\hline
\end{tabular}

Thin section examination of one of the marble sa; $;$; indicates that it consists of calcite $\left(90^{\circ}\right)$ and quart. (s is together with muscovite, pyrite and sphene. It is the nismorphosed equivalent of a calcite-rich limestone conisinin a small amount of clay. The marble is not native tis li:e Bahamas, so that it would have had to be transpirted at least a few hundred miles to Bimini. Georgia is probstifj not the source and there is only a smali chance that it coild have come from Vermont (unpublished communication from J. B. Lyons). A possible clue to its origin is the pyrite contut.

The cement cylinders are also composed of matcrial which is not indigenous to the Bahamas (unpublished communicition from R. Perkins). On balance, the material seems to the a hydrated natural cement.

Mr P. Klieger of the Portland Cement Association, Skokic. Illinois, has supported this opinion on the basis of X-ray and petrographic anatysis, as has Di R. C. Mielenz (Master Build crs, Cleveland, Ohio) on the basis of petrographic analysis. Dr R. Nurse of the Building Rescarch Station (Englind) has examined a thin section and concludes that it is a high temiser ture product and not an oxychloride cement and that "it resembles the "grappier' made from the overburnt produs of line kilns".

Mrs Bryant Mather, US Army Corps of Enginecrs (unpublished communication), says that the material comists of "calcite, brucite, a complex calcium aluminium hybrate, quartz; hydrogarnet, a little ettringite and some sort of c.slium aluminoferrite", suggesting that the material is a hydrated natural cement manufactured after about 1800 . The material also contains widely separated particies of partially corbonized coal, supporting the belief that it is a simple natural cement from lime kilns in the United States, England. France of Belgium. Long-term action of seawater on the set mitteria

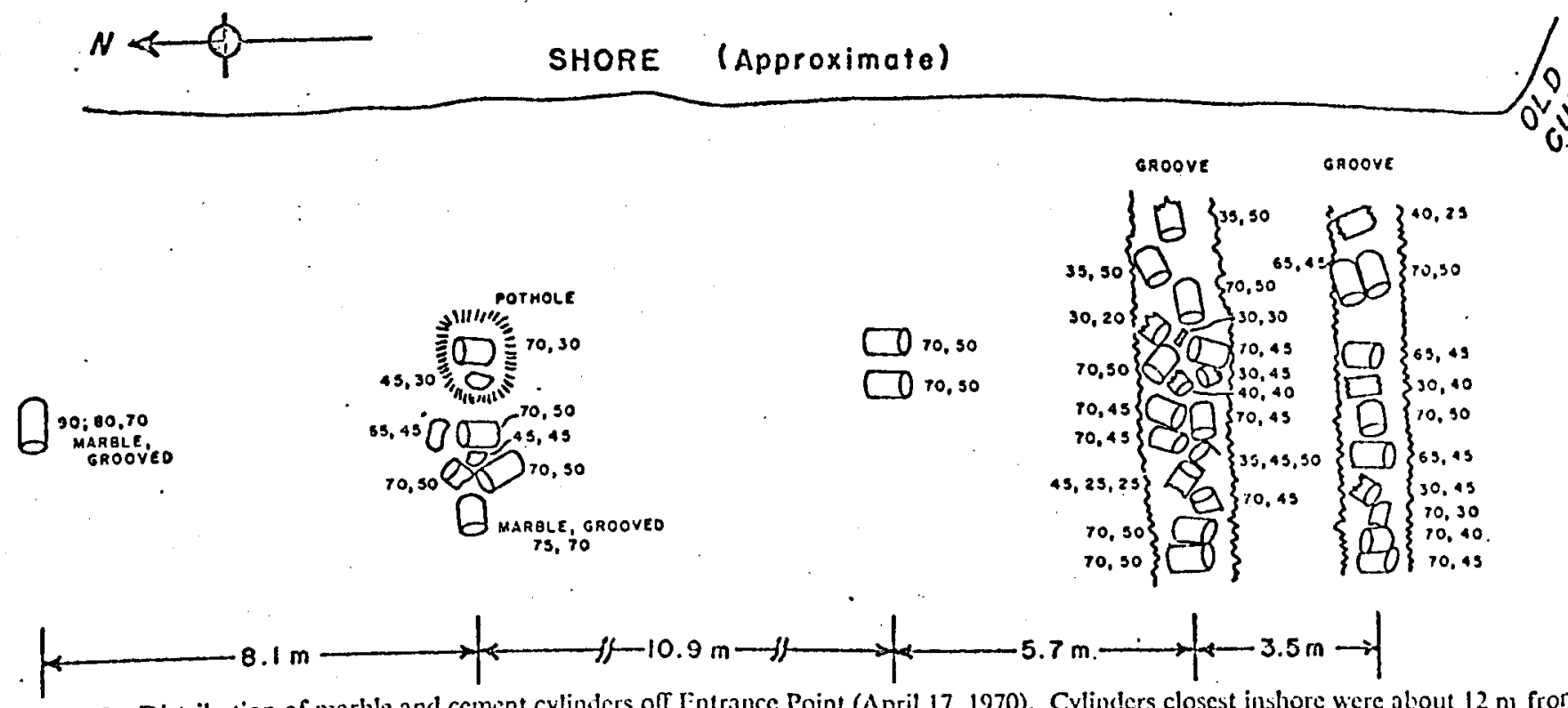
Fig. 3 Distribution of marble and cement cylinders off Entrance Point (April 17, 1970). Cylinders closest inshore were about $12 \mathrm{n}$ from
the shoreline. (First dimension is cylinder length in $\mathrm{cni}$; the second is the dianeter.) 
wolld account for sulphate, chloride, and perhaps part of the magnesiun, but an importitit proportion of the -magnesium is an original constituent of the cement.

The most striking aspect of the cylinders is the constancy in size and shape of the whole ones. They are all barrel-shaped, about $70 \mathrm{~cm}$ long and $50 \mathrm{~cm}$ in diameter (Table 1). It seems most likely that the objects were formed by cement hardening in barrels or casks. The wonden containers would have by now been bioken up and lost. The most likely cxplanation of the marble and cement cylinders is therefore that they are construction matcrials that were being transported by ship when, either by shipwreck or design, they came to rest on the scafloor of Entrance Point.

Rंeccived October 22, 1970.

1 Valentine, J. M., Mhise News, 36 (1969)

2 Marx, R. F, and Rebikon, D., Argosy' (Decomber 1969).

${ }^{3}$ Ferro, R., and Grumley, M., Allantis (Doubleday, New York, 1970); Be-litz, C., The Mystery of Atlantis (Grosset and Dunlap. New York, 1969).

4 Newell, N. D., and Rigby, J. K., Soc. Econ. Palacontologists and Mincralogists, Spece. Pub. 5, 1 (1957).

5 Ncwell, N. D, and Imbric, J., Trais. NY Acad. Sci., 2, 3 (1955). 
(Security classilfication of tillo, body of abstract and indexing annotation must be entered when the overall seport is classilicd) 1. ORIGINATING ACTIVITY (Corporato aUthor)

U. S. Army Fngineer Waterways Experiment Station Vicksburg, Mississippi

3. REPORT TITLE

IDENRIFICATION OF SAMPLES OF OBJTCTS RECOVERED FROM OCIAAI FLOOR

4. DESCRIDTIVE NOTES (Typo of report and Inclusive dates)

Final report

9. AU THOR(S) (fiat nasno, middlo initlal, last namo)

Katharine Mather

\begin{tabular}{|c|c|c|}
\hline $\begin{array}{l}\text { O. REPOAT DATE } \\
\text { January } 1973 \\
\end{array}$ & $\begin{array}{l}\text { 7a. TOTAL NO. OF PAGES } \\
17\end{array}$ & $7 b$. NO. OF REFS \\
\hline $\begin{array}{l}\text { Ba. CONTRACT OR GRANT NO. } \\
\text { b. PROJECT HO. }\end{array}$ & $\begin{array}{l}\text { 94. OnIGINATOR'S RERORT MUSí } \\
\text { Miscellaneous Paper }\end{array}$ & C $-73-4$ \\
\hline $\begin{array}{l}\text { c. } \\
\text { d. }\end{array}$ & $\begin{array}{l}\text { 9b. OTHER REPORT HOlsi (Any ot } \\
\text { this ropori) } \\
\text { CTIAC Report } 6\end{array}$ & 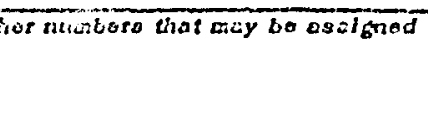 \\
\hline
\end{tabular}

10. DISTRIUUTION STATEMENT

Approved for public release; distribution unlimited.

11. SUPPLEMENTARY NOTE9

12. SPONSORING MILITARY ACTIVITY

\section{ADSTRACT}

Several pieces of objects recovered from the ocean floor near Bimini were examined by $\mathrm{X}$-ray and analyzed petrographically. The objects consisted of calcite, brucite, a complex calcium aluminum hydrate, quartz, hydrogarnet, a little ettringite, and some sort of calcium alumino-ferrite. The objects are believed to be remnants of construction materials that were being transported by ship and subsequently came to rest (perhaps because of shipwreck) on the ocean floor. A copy of an article written for Nature by $M r$. Wyman Harrison in which the findings of the examination mentioned above are cited is included as Appendix A. 
Unclassified

Security Classification

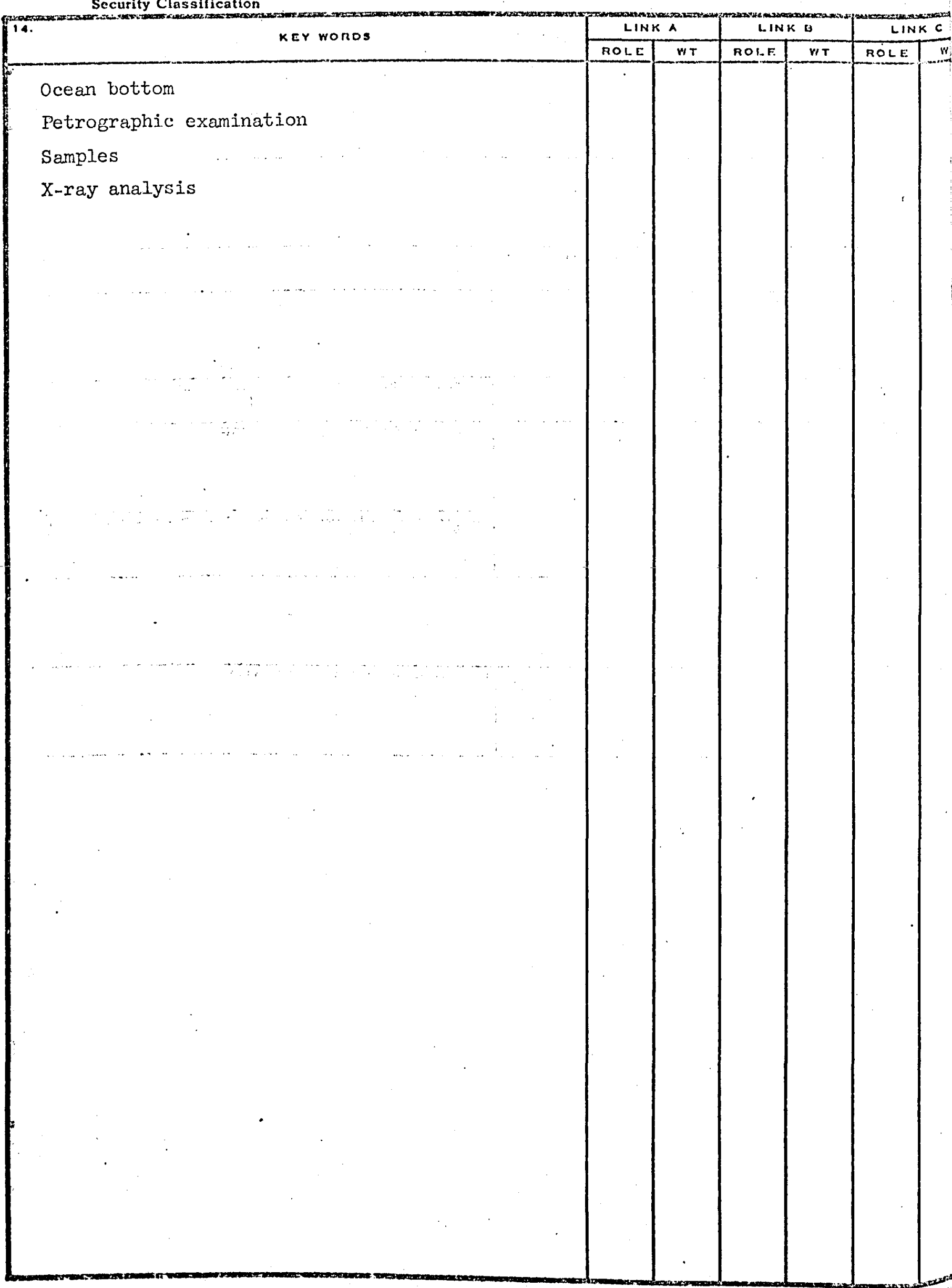

Unclassified

Security Classiflcation 